\title{
Longitudinal tracking of academic progress during teacher preparation
}

\author{
Roisin P. Corcoran ${ }^{1,2 *}$ (D) and Joanne O'Flaherty ${ }^{3}$ \\ 'IRINSTITUTES, Dover, DE, USA \\ ${ }^{2} \mathrm{UCD}$, Ireland \\ ${ }^{3}$ University of Limerick, Ireland
}

Background. Given that the ultimate academic goal of many education systems in the developed world is for students to graduate from college, grades have a considerable bearing on how effective colleges are in meeting their primary objective. Prior academic performance informs predominantly the selection and retention of teacher candidates. However, there remains a dearth of evidence linking academic performance with outcomes in teacher preparation or the workplace.

Aim. This study examined pre-service teachers' trajectories of academic growth during teacher preparation.

Sample. The sample comprised 398 pre-service teachers - $282(70.8 \%)$ males and I 16 (29.1\%) females.

Method. Academic growth was measured across eight time points over the course of 4 years. Pre-service teachers' academic growth was analysed using linear and nonlinear latent growth models.

Results. Results indicate that academic growth was quadratic and, over time, decelerated, with no evidence of the Matthew effect or the compensatory effect. There was evidence of a connection between prior academic attainment and current grades.

Conclusion. Greater attention to academic growth during the college years, and particularly among pre-service teachers, may enable greater achievement support for students.

Set against a context of increasing levels of accountability and reduced budgets in higher education, sustained academic growth is a key concern in education policy and practice at both second and tertiary level, not least due to the use of second-level student outcomes as a predominant means of selection for tertiary level. Many authors (Astin \& Antonio, 2012; Banta, Jones, \& Black, 2009; Corcoran \& O'Flaherty 2016a,b, 2017; Kim \& Corcoran, 2017; O'Flaherty \& Gleeson, 2017; Walvoord, 2010) have highlighted the importance of researching student success assessments in college and assert that results from such assessments should inform programmatic development. While most institutions use performance-based assessments of academic outcomes to ensure consistency among graduates (e.g., the ACT, American College Testing; the SAT, Scholastic Assessment Test and

\footnotetext{
*Correspondence should be addressed to Roisin P. Corcoran, IRINSTITUTES, 8 The Green, Suite 5992, Dover, DE I990I, USA (email: rcorcoran@irinstitutes.org).

[The copyright line for this article was changed on $15^{\text {th }}$ March 2018 after original online publication]
} 
the GPA, high school grade point average), explicit attention to trajectories of academic growth is minimal to non-existent in most teacher-preparation programmes. Therefore, it is important to identify whether such relationships exist between prior academic achievement (AA) and college-level outcomes, as this may have consequences for selection procedures.

Contemporary research studies have reinforced the idea that 'effective teachers' contribute to worthwhile student educational outcomes (Brabeck et al., 2016; Corcoran, 2017a,b; Glazerman et al., 2010; Harris, 2012; MET Project, 2012; Weisberg, Sexton, Mulhern, \& Keeling, 2009), with the Organisation for Economic Co-operation and Development (OECD, 2005) suggesting that 'quality of teaching' was determined to be 'the single most important school variable influencing student achievement'. The majority of pre-service teachers engage in teacher-preparation programmes offered by colleges and universities. 'The need for evidence of high-quality teacher candidates arises from the ethical and professional responsibility of teacher-education programs to assure the public that they are preparing effective teachers for diverse learners' (Brabeck et al., 2016, p. 161). Therefore, the more we can learn and understand about student AA at teacher preparation, the more we can inform our programme structure and teacher preparation in terms of quality of instruction, curricular content, student values, engagement, and setting objectives (Corno \& Mandinach, 2004; Schunk, 2008).

Currently, the dominant policies vis-à-vis teacher quality stress 'value-added' approaches that quantitatively link teacher-preparation type and duration to students' AA. However, drawing attention to the need to address trajectories of academic growth during teacher-preparation programmes can inform parallel discussions among school and district leaders, school psychologists, and other professionals who influence the education of children and adolescents in PreK-12 schools. More recently, the interindividual and intra-individual measurement of academic growth has been of particular interest.

As the issue of teacher quality, quality of teacher preparation, and the quality of schools gains more traction with policymakers, they have begun to understand the need to consider student academic development, as opposed to student achievement scores alone. Prior academic performance has been linked to student retention; cognitive ability; college admissions; dropout and future academic performance (Cabrera, Nora, Terenzini, Pascarella, \& Hagedorn, 1999; Ishitani \& Desjardins, 2002; Noble \& Sawyer, 2002; Stumpf \& Stanley, 2002). The evidence also confirms that grades are a consistent indicator of student retention in higher education (Corcoran \& O'Flaherty, 2017; Duckworth, Peterson, Matthews, \& Kelly, 2007; Pascarella \& Terenzini, 2005). While there is a dearth of literature evidencing pre-service teachers' academic growth, Hill, Rowan, and Loewenberg Ball (2005) report that teachers' mathematical knowledge is significantly related to student achievement gains in both first and third grades. While the relationship between academic success and performance in high school with academic performance in first year is recognized, it remains unclear whether such a relationship exists with academic performance beyond the first year (Zwick, 2006). Greater attention to academic growth during the college years, and particularly among pre-service teachers, may enable greater achievement support for students. Grades have important consequences for students, schools, and the broader education system. While many students may not have the capacity to outperform their peers, they do have the capacity to improve on their own previous efforts, indicating that there is always room for individual growth. Much attention has been paid to elementary and secondary AA. As far as we know, there is no existing research tracking 'real' growth of pre-service teachers' academic progress and, in an era where we try to attract and retain the highest quality teacher candidates, this merits further attention. This study seeks to address this gap. 


\section{Theoretical framework}

In this section, we present our conceptual framework for the paper, reviewing the evidence showing academic trajectories and links between prior AA and subsequent academic performance, most of which come from younger children (preschool-aged), adolescents (elementary school), or young adults (high school and college-aged). Links between college performance and work-related outcomes, college-level outcomes for teachers, and work-related practice are also discussed.

\section{Previous research on student growth trajectories}

Worldwide, efforts to improve student academic outcomes have become an ongoing endeavour. While mathematics and reading have received much attention due to their links with social and economic returns (Anderman, Gimbert, O'Connell, \& Riegel, 2015; Grimm, 2008), no empirical study has been conducted on academic growth trajectories of pre-service teachers. In this study, trajectories of academic grades during teacher preparation are examined. While Ready (2013) acknowledges the sophisticated development of measures of student growth, we still have a paucity of evidence examining the relationship between student achievement and overall achievement growth: That is, do students that achieve initial higher scores grow at a faster pace than lower-achieving students? Therefore, sustained within-person growth is increasingly important (Anderman et al., 2015; Martin, 2007, 2015; Martin \& Liem, 2010; Mok, McInerney, Zhu, \& Or, 2015). If we are to better understand growth for the individual student, researchers need more information on change over time, with an increased number of time points (that is more than two; Hedeker \& Gibbons, 2006; McCoach, Madura, Rambo-Hernandez, O'Connell, \& Welsh, 2013; Raudenbush, 2001). The use of GPA and other such standardized tests have been problematized across various research studies as a consistent measure of academic performance, as the application of assessment criteria cannot be applied systematically and objectively across different disciplines (Johnson, 1997; Strenta \& Elliot, 1987). However, Westrick, Le, Robbins, Radunzel, and Schmidt (2015) purport that it is better to compare academic performance in years one and two of college, as students engage more frequently with general education courses, as opposed to major specific courses.

Two reciprocal activities can take place when considering the connection between academic attainments at various points of time: The first is the Matthew effect and the other is the Compensation effect. The former is described by Shin, Davison, Long, Chen, and Heistad (2013, p. 93) as 'the achievement rich get richer and the poor get poorer'. This means there is a higher rate of achievements scores for those students that start their education with higher achievement levels, compared to those whose education starts with lower attainment rates. At the same time, their academic growth is faster. The result of the Matthew effect is that it widens the gap that already exists between the two types of student (Muthen \& Khoo, 1998; Shin et al., 2013). The latter (the Compensatory effect) is less common (Shin et al., 2013) and applies to those who start with lower achievement but compensate by increasing their growth more quickly than those who entered education with a higher level of attainment (Davis-Kean \& Jager, 2014; Rescorla \& Rosenthal, 2004). In this way, they succeed in narrowing the achievement gap. One researcher (Ready, 2013) has noted the Compensation effect in the subjects of literacy and mathematics.

Shin (2007) conducted a 4-year longitudinal study that comprised 1,244 students that utilized hierarchical linear modelling (HLM), latent growth modelling (LGM), and 
multidimensional scaling applied to longitudinal profile analysis (LPAMS) in order to detail the growth in student achievement trajectories from Grade 2 to Grade 5. Shin's results supported the use of LGM for longitudinal research with nested data and large sample sizes.

\section{Links between prior academic attainment and college performance}

In their seminal work, Berdie, Layton, Swanson, and Hagenah (1963) found that educational achievement in later life often depends on educational attainments in earlier life. Their research established strong associations between high school and college academic grade averages of about .50 (Berdie et al., 1963). Previous research in the area has attested to the high correlations between standardized test scores and high school GPA, both of which contribute to predicting academic performance (ACT, 2007; Allen, Robbins, Casillas, \& Oh, 2008; Bridgeman, Pollack, \& Burton, 2008; Kobrin, Patterson, Shaw, Mattern, \& Barbuti, 2008; Mattern \& Patterson, 2011a,b). Zwick (2006) supports the call for further research to determine the association between high school standardized test scores and high school performance with first-year college/university academic performance have been established. However, these associations with academic performance beyond the first year have received less scrutiny in the extant literature. Set against a context of increased demand for accountability of student performance and constrained budgets in higher education, the exploration of college student outcomes has gleaned much attention. Many authors (Astin \& Antonio, 2012; Banta et al., 2009; Walvoord, 2010) have highlighted the importance of research on college student outcomes assessment and have suggested that results from such assessments should inform programmatic development. Consistent across these publications is the suggestion that a number of varying assessment modes should be utilized, yet many institutions continue to use standardized examinations. Bagg (1970), in his seminal study, suggested that measures such as A-level (upper secondary level standardized high-stake examination) grades do not necessarily predict university attainment. Westrick et al. (2015) completed a meta-analysis that examined the associations of ACT composite scores, high school grades, and socioeconomic status (SES) with academic performance and retention in higher education. Based on a sample size of 189,612 students across 50 institutions, findings indicate a strong correlation between that ACT composite scores with high school GPA for first-year academic performance. This first-year AA also emerged as the strongest predictor of persistence into second and third years. McManus, Woolf, Dacre, Paice, and Dewberry (2013) analysed data from five longitudinal studies to investigate if early academic performance is predictive of later educational outcomes. Accounting for the limited range of entrants, results indicate that medical students' A-level results correlated weakly with undergraduate and postgraduate performance. However, there was restriction in the range of entrants. General Certificate of Secondary Education (GCSE)/O-level results (lower secondary level standardized state examination) have also been highly predictive of undergraduate and postgraduate outcomes, but not to the same degree as the A-level results.

Grades have also been linked to other student outcomes. For example, a number of researchers have reported trends between elementary school grades, and student dropouts for both middle school and high schools, independent of other variables such as SES (Alexander, Entwisle, \& Kabbani, 2001; Ensminger \& Slusarcick, 1992; Greene \& Forster, 2003; Rumberger, 1995). Furthermore, high school grades are highly predictive of 
college admissions and, subsequently, first-year college performance (Camara \& Echternacht, 2000; Noble \& Sawyer, 2002; Stumpf \& Stanley, 2002) and have been found to predict college dropout and completion rates (Astin, Tsui, \& Avalos, 1996; Camara \& Echternacht, 2000; Strenta, Elliott, Adair, Matier, \& Scott, 1994). While research has established the ability to predict prior AA on academic performance, much has focused on stable between-person associations between these constructs. Furthermore, few studies have investigated how academic performance during college changes over time within the individual and factors influencing these academic trajectories.

Previous randomized controlled studies suggest evidence supporting the importance of personal goal-setting on academic performance (Locke \& Latham, 2002; Morisano, Hirsh, Peterson, Pihl, \& Shore, 2010; Seijts, Latham, \& Woodwark, 2013). Diseth and Kobbeltvedt (2010) and Martin (2013) report the positive impact of achievement on academic growth. Hirsh, Mar, and Peterson (2012) and Morisano et al. (2010) discuss psychological uncertainty as potential contributing factors to performance improvements and reductions, while others hypothesize that students' anxiety about post-high school plans can impact academic performance (Perry, Hladkyj, Pekrun, Clifton, \& Chipperfield, 2005).

In sum, grades are a central aspect of how effective colleges and teacher-preparation programmes are in meeting their primary objective and affect students' future success. Although many criteria are utilized for assessing teacher preparation and teacher quality, there exists an important gap in the literature on student teachers' academic growth during college; the association between students' initial academic performance and growth rate; and issues influencing academic growth rates. This study seeks to address this gap.

\section{Methodology}

This study aimed to address the following three research questions:

1. Does academic growth among student teachers follow a quadratic or linear trajectory?

2. Is there evidence to suggest that a relationship exists between student teachers' initial academic performance at Semester 1 and the growth rate in academic grades?

3. Are there differences between student teachers' initial grades and growth rates, depending on prior AA?

\section{Participants and research context}

The participants recruited for this study were first-year undergraduates registered with a 4year concurrent teacher preparation programme in the Republic of Ireland. There are consecutive models in addition to concurrent models of teacher preparation available in this country. Ireland, like other jurisdictions, including Finland and Korea, experiences high levels of competitiveness for entry into teacher preparation (OECD, 2005), and new qualified graduates continue to enjoy the high social status of the profession (see Corcoran \& Tormey, 2012 for an evaluation of the research context).

The study participants were admitted to their programme based on achievement scores on the high-stakes, state-run, examination (the Leaving Certificate). The Leaving Certificate Examination attracts much public attention as results achieved by students in this examination determine entry to third-level education. The model of evaluating curriculum knowledge demonstrates central government control: 'written, as opposed to oral, manual or other, abilities are emphasized ... the ability to perform alone and under 
time-pressures is also an unwritten determinant of success' (Lynch, 1989, p. 42). The system generally 'rewards egocentricism highly and sanctions altruism severely ... it imposes penalties on cooperative effort at times of evaluation' (Lynch, 1989, p. 43). The examination-driven culture of education leads to a nature of competitiveness, 'where one works for extrinsic gain rather than for intrinsic value' (Lynch, 1989, p. 44). Lynch (1989) contends that 'competitive individualism is an endemic part of life in second-level schools' (p. 87).

The student teachers participating in this study were enrolled in a concurrent, teacherpreparation programme based on the academic traditional model of teacher preparation (Musset, 2010), which is comprised of three components: pedagogy, foundational studies, and field experience disciplines (Teaching Council, 2011). The programme reflects a 'hermeneutic view of teacher education as practical science' (Elliott, 1993, p. 17).

The concurrent 4-year programme is conceptualized around a 'spiraled framework' (Leonard \& Gleeson, 1999, p. 37): The first year is devoted to the self; the second year focuses on the classroom; in the third year, the school becomes a priority, while the fourth year returns to a focus on the self, however, the context shifts to professional conduct of the teacher within the school. The student teachers split their time between education studies modules and modules of their own subject specialization. Some $20 \%$ of the credits are given to studies in education, with the subject specialization providing the nexus of the programme, together with a dedicated focus on hermeneutic approaches in addition to reflective practices. The Teaching Council of Ireland (2013) recently mandated that $25 \%$ of all teacher-preparation programmes should be allocated to School Placement experiences. Students complete a 6-week School Placement in their second year in addition to a 10-week placement in their final year. Students must complete some 20 modules dedicated to their subject discipline(s).

The sample comprised 398 student teachers, of which, 282 (70.8\%) were males and $116(29.1 \%)$ were females. While gender distributions were broadly representative of the university intake, they also reflected a skew towards male-orientated teacher-education programmes, in that more than half of the sample were registered in STEM (Materials and Architectural Technology and Materials and Engineering Technology) teacher preparation programmes. Student teachers' ages ranged from 17 to 47 years $(M=19.90$, $S D=3.66$ ).

\section{Measures}

\section{Grades}

The quality of a student's academic performance is represented as a numerical average in the credited modules that were completed by the student. This weighted average is called quality credit average (QCA), or GPA, and is calculated at the end of each semester and cumulatively for each programme. The GPA from 2010 to 2014 for each of eight semesters over 4 years was obtained from official student records, on a conventional scale ranging from $\mathrm{F}(0)$ to $\mathrm{A}(4)$.

\section{Academic achievement measure}

The method of measuring the participants' previous academic attainment was based on their scores in the Leaving Certificate. A comprehensive account of this Irish state examination system is provided by Gormley and Murphey (2006). 


\section{Analytic issues}

Latent growth modelling

Anderman et al. (2015) suggest that similar data can provide highly inconsistent interpretations when dissimilar types of growth models are applied. In the context of this study, LGM was conducted using Mplus 7.11 (Muthen \& Muthen, 2011) to better understand students' growth in academic grades over eight semesters across 4 years. LGM contains more information than cross-lags, for example. While cross-lags do capture intraindividual differences (the scores of the individual on the measured indicators are reproduced as a score on the latent factor), the latent mean and variance is fixed at each time point, so there are no degrees of freedom on Level 1 (intra-individual differences), meaning that intra-individual differences cannot be examined. This study employed the use of the robust maximum-likelihood estimator (MLR) for model estimation (Yuan \& Bentler, 2000). With LGM, the terms intercept and slope are used to describe discrete patterns of change for particular constructs that are modelled as latent factor variables. The factor loadings were fixed at 1.0. For the linear estimation of grades growth model, by using 0 for the first loading of the slope, the first measurement is set as the starting level. The loadings for linear growth are $0,1,2,3,4,5,6$, and 7 for the subsequent measures. This assumes that the growth trajectory of the slope is linear and that changes in grades have a proportional effect that is constant over time. In other words, it does not assume that growth trajectories can change across time points. This may conflict with expectations and with the data, in the sense that growth trajectories may have a more curvilinear or quadratic form. Specifically, LGM models require four or more data collection occasions to properly identify the addition of a quadratic latent factor. Specifying the model in this way allows the data to tell us what the change is across time points. Figure 1 illustrates the hypothesized unconditional linear and quadratic LGMs.

Latent growth modelling is a continuation of SEM (structural equation modelling procedures). It applies the same criteria for how well the observations fit, and allows successively nested models to be compared and contrasted. Our model measured all constructs with a single indicator, thus incorporating all observed variables. To follow is a list of the indicators employed in our study and chosen in relation to suggestions from earlier researchers (Cole, 1987; Marsh, Balla, \& McDonald, 1988): the root-mean-squared error of approximation (RMSEA); the Tucker-Lewis Index (TLI); and the Comparative Fit Index (CFI), as used in Mplus, together with the MLR estimator. Robust chi-square test statistic and the parameter estimates were also evaluated for this study. The principles we used to illustrate that the observations were a good match included the following: CFI $>.9$, TLI $>.85$, and RMSEA $<.08$. These were founded in a number of studies (Anderson \& Gerbing, 1984; Cole, 1987; Marsh et al., 1988; McDonald \& Marsh, 1990). Time-invariant controls were added at the next stage of the process (gender - dummycoded - and AA - as continuous variables).

\section{Results}

\section{Growth models of student teachers' academic growth trajectories}

Descriptive statistics and correlations of the mean grades of students in semesters 1-8 are presented in Table 1. Results indicate an average decrease over time for students. Nonetheless, the between-semester variation was smaller than the variations withinsemester. Further, there were indications of heterogeneous error variance of 

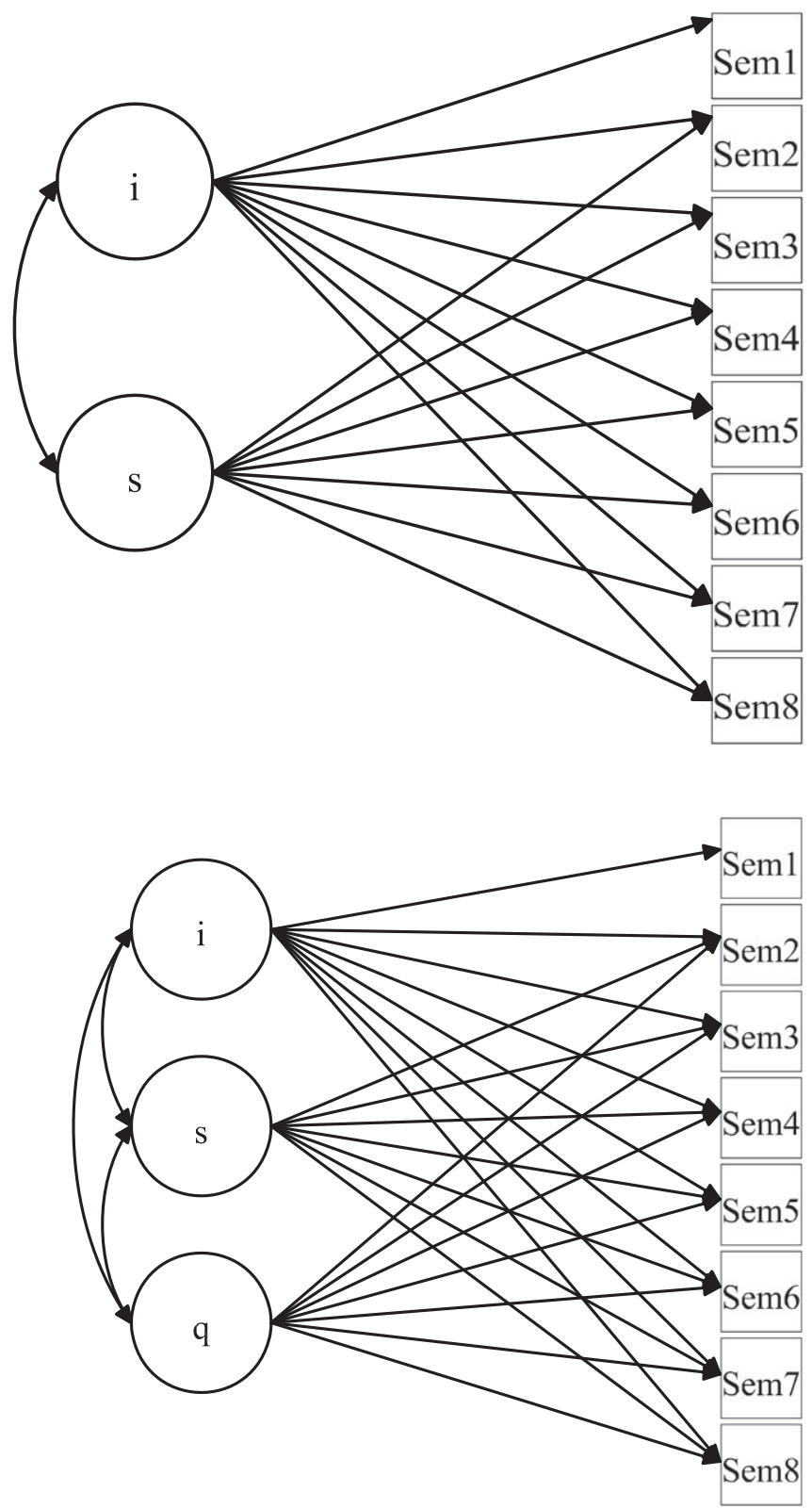

Figure I. Hypothesized unconditional linear and quadratic latent growth models for students' achievement in semesters I-8. Note. Sem stands for 'Semester'; 'i', 's', and 'q' stand for intercept, slope and quadratic.

measurement over time, providing added justification for selection of LGM over other methods (Shin, 2007).

Table 2 shows the fit indices and fit statistics of the models. It can be seen from Table 2, an unconditional linear model of the growth curve for grades indicates a mediocre model fit. Table 3 shows the parameter estimates for the models. Results 


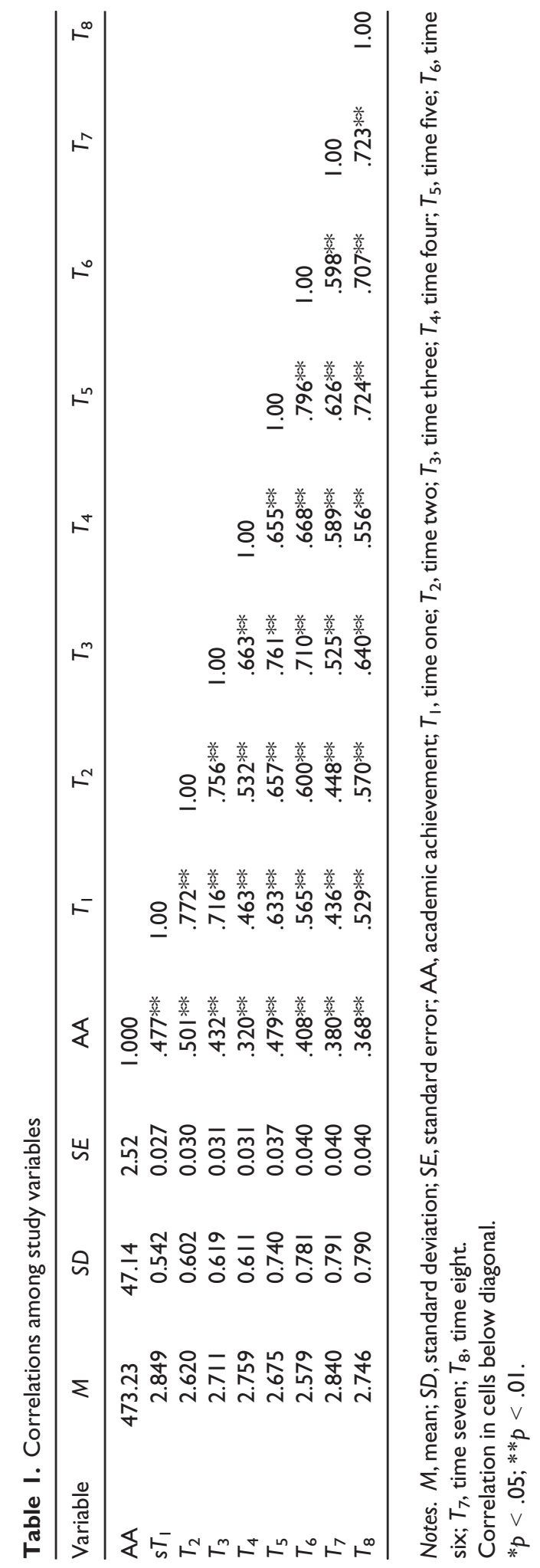




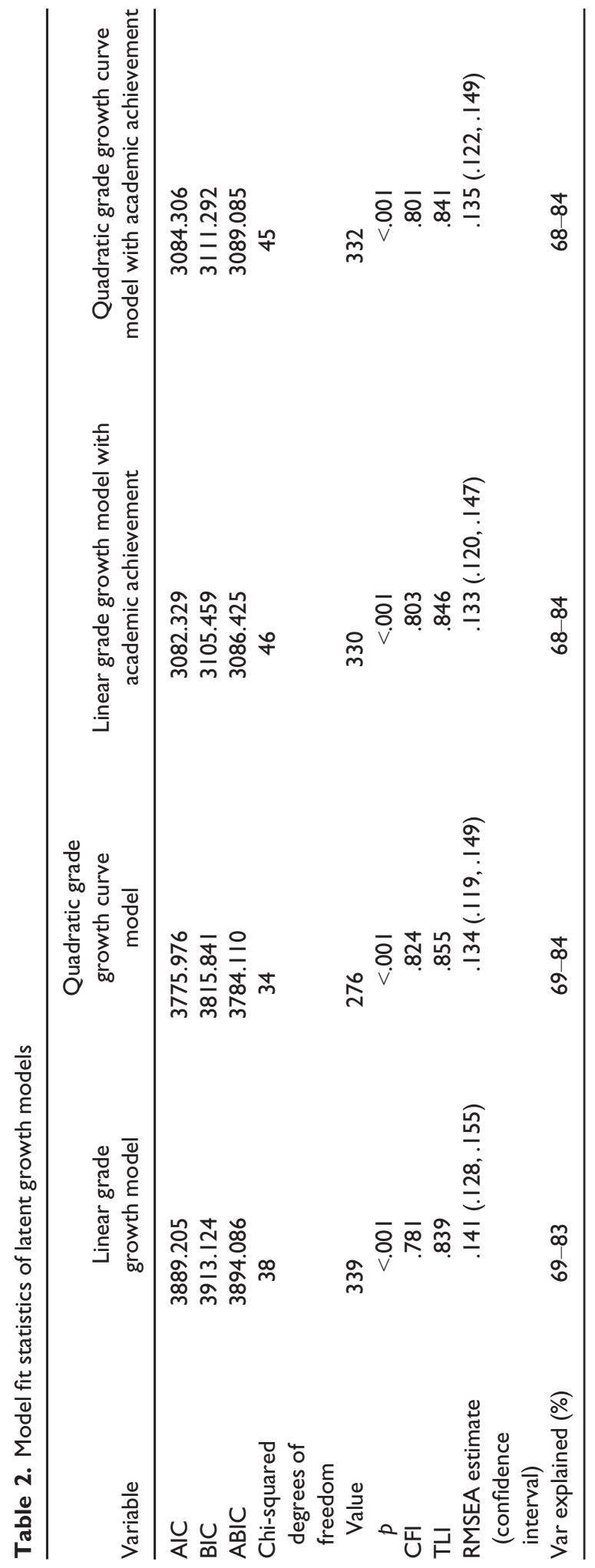


Table 3. Parameter estimates for latent growth models

\begin{tabular}{lcc}
\hline Variable & Linear grade growth model & Quadratic grade growth curve model \\
\hline Intercept mean $(p)$ & $2.705(<.00 \mathrm{I})$ & $2.782(<.00 \mathrm{I})$ \\
Mean slope $(p)$ & $0.001(.845)$ & $-0.076(<.00 \mathrm{I})$ \\
Quadratic slope $(p)$ & - & $0.01 \mathrm{I}(<.00 \mathrm{I})$ \\
Intercept var $(p)$ & $0.261(<.00 \mathrm{I})$ & $0.229(<.00 \mathrm{I})$ \\
Slope var $(p)$ & $0.007(<.00 \mathrm{I})$ & $0.026(.00 \mathrm{I})$ \\
Quadratic var $(p)$ & - & $0.001(.028)$ \\
\hline
\end{tabular}

indicate variation among students' initial grades achievement, while the mean slope was not significantly different from zero.

It can also be seen from Table 2, a quadratic model of the growth curve for grades indicates a mediocre model fit. This model had improved model fit compared to the previous linear model $\left(\Delta \mathrm{CFI}=.043, \Delta \mathrm{TLI}=.016, \Delta \chi^{2}=63, \Delta \mathrm{df}=4, p<.001\right)$. Further, the AIC, BIC and ABIC values were larger for the linear model than the quadratic model. Table 3 shows that the means at time 0 were significantly different from 0 , and there was a decrease in the longitudinal mean change of grade over successive time periods.

\section{Relationship between student teachers' academic performance at Semester I and academic growth trajectories}

In terms of the linear model of the growth curve for grades, considerable differences were observed between individuals, both in the levels of early scores in grades and in their growth paths. A minor link $(r=.156, p=.068)$ between the intercept and slope shows that there was little difference in the rates at which participants grew, according to their beginning levels of academic performance.

For the quadratic model of the growth curve for grades, acceleration of slope decreased with .01 per time point. Considerable differences were observed between individuals, in levels of academic performance, in growth paths, and in rates of growth. A major link $(r=-0.846 p<.001)$ between the linear and quadratic slope shows that acceleration of the decrease in average grade scores experienced by participants over time was more rapid than that of the opposite scenario - that is, the increase in average grade scores by other participants.

\section{Relationship between prior AA and student teachers' initial grades and academic growth trajectories}

The next model included the results of the linear growth model for grade scores with AA the time-invariant control added. This model resulted in a mediocre overall fit. This model had a better comparative fit relative to the unconditional linear model; there were some differences in model fit stats $\left(\Delta \mathrm{CFI}=.02, \Delta \mathrm{TLI}<.01, \Delta \chi^{2}=9, \Delta \mathrm{df}=8, p=.342\right)$; however, they did not indicate a significant difference. There was a positive influence of prior AA on initial levels of grade scores $(\beta=.551 p<.001)$. However, prior AA had no significant effect on the linear growth of grade scores in the model.

The last model included the findings of the quadratic growth model for grade scores with AA added. This model resulted in a mediocre fit. This model did not fit the data well 
compared to the previous model. There was a positive influence of prior AA on initial levels of grade scores $(\beta=.552 p<.001)$. However, prior AA had no significant effect on the growth of grade scores in the model.

\section{Discussion}

To our knowledge, there has been no published research on academic trajectories and the impact of prior achievement on academic trajectories in a student teacher population. In the present study, using rigorous methods and advanced analytic techniques, the growth of academic grades during students' pre-service teacher education programmes was examined. Further, this study tested whether prior academic attainment, a time-invariant control, would predict achievement trajectories. The results led to three conclusions.

First, the findings suggest that academic grades growth is quadratic and decelerates during pre-service teacher preparation. Many researchers have offered explanations as to why academic growth decelerates, including the fact that higher education is more rigorous than second-level education (Shin et al., 2013) and students may therefore experience reduced levels of motivation (Martin, 2007; Metallidou \& Vlachou, 2010). Other factors may include students' self-efficacy beliefs (King \& McInerney, 2014; Pinxten, Marsh, De Fraine, van den Noortgate, \& van Damme, 2014); students' perceived value of content (Metallidou \& Vlachou, 2010) and level of engagement (Pascarella, Pierson, Wolniak, \& Terenzini, 2004) during the transition from second-level education to higher or further education. A number of factors, for example persistence and feedback, have also been identified as having an impact on academic growth (Travers, Morisano, \& Locke, 2015).

Second, there is no evidence of Matthew (Shin et al., 2013) or compensatory effects (Rescorla \& Rosenthal, 2004). Up until now, there has been no published research examining whether grades growth for student teachers demonstrated Matthew, compensatory, or neither effects. The findings indicate there was no change in the achievement gap during college. Dweck (2015, p. 243) suggests that we need to broaden our methodological approach to include studies which measure 'students' growthrelevant beliefs or goals and then closely observe their thoughts, feelings, actions, and outcomes as they perform a task', as many students have a tendency to infer that intelligence has the propensity to be developed (a growth perspective), while others may hold that intelligence is fixed. Having a better understanding of these psychological mechanisms will lead to the design of appropriate and effective assessment interventions. Dweck (2015) further hypothesizes that taking a more holistic approach to achievement and growth goals will provide insights into students' value of learning, hard work, and resilience in the face of setback or failure (Blackwell, Trzesniewski, \& Dweck, 2007; Dweck, 1999).

A third conclusion was that there was evidence of an association between students' prior academic attainment and academic grades. The relationship is positive, and this suggests that students who tend to have higher AA scores also score higher on academic grades. The relationship is a moderate correlation which accounts for a substantial proportion of the variance in the initial levels of grade scores. The associations between students' prior academic attainment and academic grades presented in this research mirror the findings in other studies (Bridgeman et al., 2008; Kobrin et al., 2008; Westrick et al., 2015), further validating utilizing this measure for selection and admission decisions. It is notable, however, that AA did not have a significant effect on the growth in 
academic grades. The literature was inconclusive concerning the relationship between students' prior academic attainment and grades. These findings could result from the high societal expectation concerning grades for higher and lower achievers, or there may not be any real difference based on prior AA.

\section{Limitations}

It is important to acknowledge several limitations encountered in this study. First, this study focuses on academic grades from official student records. This measure is a weighted average that describes a student's performance over all modules the student had taken to date. This can be a useful measure for practical outcomes assessment related to various academic programmes. However, the study does not report on standardized tests, although the results on these measures are likely to be important for researchers and educators alike. Second, due to the scope of this study, only students from a teacherpreparation programme in Ireland were included. However, every university is different, and findings from studies done elsewhere cannot be assumed to generalize to a specific university or set of universities. More studies with rigorous designs conducted by multiple researchers with many diverse students and programmes are needed, so that we can build up a large and diverse evidence base for programmes that can be replicated and to determine the 'value-added' of teacher preparation programmes. Further, teacher education programmes benefit from such value-added assessment models and can use these models to support student teachers to become aware of their own progress.

\section{Conclusions}

Over the past few years, the broader discourse concerning teacher preparation and teacher quality has received a high level of media attention. A number of factors must be considered when assessing teacher education programmes, including the educational context, the impact of candidate selection, and the impact of market-driven forces on supply versus demand (Worrell et al., 2014). What, therefore, are the implications for teacher preparation arising from the current study?

The actual characteristics of the students themselves must be considered when attempting to explain these results, as we strive to continue to attract and retain a highquality teaching profession. As suggested by Pascarella and Terenzini's (2005) assessment of single-institution and national studies, 'virtually without exception, students' grades make statistically significant, frequently substantial, and indeed often the largest contribution to student persistence and attainment' (p. 397). Results from the current study reinforce selection criteria for those who choose teaching as a profession. As noted earlier, in Ireland, the teaching profession is well respected, and the calibre of Irish student teachers is high by international standards. According to an OECD report (1991, p. 100), 'Ireland has been fortunate in the quality of its teaching force'. This sentiment is further endorsed by Coolahan (2003, p. 21), who suggests 'there are not major concerns in Ireland about attracting competent people to enter the teaching profession. . . [with] keen competitiveness for entry to all categories of teaching. ... Over $90 \%$ of entrants to the Higher Diploma in Education for secondary teaching hold honours degrees, and high performance in the Leaving Certificate Examination is required from those taking the concurrent course'. Results from this study prove to support this discourse, in addition to supporting our selection processes. 
However, this research also suggests that academic growth recedes while students are completing teacher preparation. This has implications in terms of how we design and conduct assessment. Perhaps, generally, there is a disconnect between what students learn about assessment strategies during teacher preparation and those that are actually used. This would suggest that those involved in the preparation of teachers should debate more rigorously and publically the competences of the novice professional that need to be fostered within teacher preparation - what do we value, and therefore, how do we asses them? This would also lend itself to the inclusion of a variety of assessment types which align with these core competencies. Another implication for teacher preparation is the importance of including structured feedback processes following assessment, as research already suggests that feedback has a substantial effect on student learning (Hattie, 2015). This may, in turn, have an impact on growth during teacher preparation.

Both practitioners and policymakers need to consider to what extent current practices, like high-stakes standardized testing, evaluation, and reward practices, that are highly focused on a students' current ability (rather than the cultivation of student ability over time), may be contributing to an environment that mitigates genuine development in students as well as educators.

Based on the above results, further research in this area ought to consider pre-service teachers' current thinking about growth - can students be supported to identify goals that lead to intellectual growth? How can we best measure and model when growth has occurred? And, what are possible reasons for the decelerated growth rate in improving the effectiveness of novice teachers? Creating a culture that is focused on assessment for learning will improve teachers' practice and students' outcomes - a robust impact of practical and policy importance.

\section{Acknowledgements}

This work is supported by an early career award from the American Psychological Association Division 15 (Educational Psychology) to Roisin P. Corcoran (Grant Number: 116839) and by the Irish Research Council (IRC) (Grant Number: REPRO/2015/111).

\section{References}

ACT (2007). The ACT technical manual. Iowa City, IA: Author.

Alexander, K. L., Entwisle, D. R., \& Kabbani, N. (2001). The dropout process in life course perspective: Early risk factors at home and school. Teachers College Record, 103, 760-822. https://doi.org/10.1111/0161-4681.00134

Allen, J., Robbins, S., Casillas, A., \& Oh, I. (2008). Third-year college retention and transfer: Effects of academic performance, motivation, and social connectedness. Research in Higher Education, 49, 647-664. https://doi.org/10.1007/s11162-008-9098-3

Anderman, E. R., Gimbert, B., O'Connell, A. A., \& Riegel, L. (2015). Approaches to academic growth assessment. British Journal of Educational Psychology, 85, 138-153. https://doi.org/10.1111/ bjep. 12053

Anderson, J. C., \& Gerbing, D. W. (1984). The effect of sampling error on convergence, improper solutions, and goodness-of-fit indices for maximum likelihood confirmatory factor analysis. Psychometrika, 49(2), 155-173. https://doi.org/10.1007/bf02294170

Astin, A. W., \& Antonio, A. L. (2012). Assessment for excellence: The philosophy and practice of assessment and evaluation in bigher education (2nd ed.). New York, NY: Rowman \& Littlefield/American Council on Education. 
Astin, A. W., Tsui, L., \& Avalos, J. (1996). Degree attainment rates at American colleges and universities: Effects of race, gender, and institutional type. Los Angeles, CA: Higher Education Research Institute, Graduate School of Education, University of California.

Bagg, D. G. (1970). A-levels and university performance. Nature, 225, 1105-1108. https://doi.org/ $10.1038 / 2251105 a 0$

Banta, T. W., Jones, E. A., \& Black, K. E. (2009). Designing effective assessment: Principles and profiles of good practice. San Francisco, CA: Jossey-Bass.

Berdie, R. F., Layton, W. L., Swanson, E. O., \& Hagenah, T. (1963). Testing in guidance and counseling. New York, NY: McGraw-Hill.

Blackwell, L. S., Trzesniewski, K. H., \& Dweck, C. S. (2007). Implicit theories of intelligence predict achievement across an adolescent transition: A longitudinal study and an intervention. Child Development, 78, 246-263. https://doi.org/10.1111/j.1467-624.2007.00995.x

Brabeck, M. M., Dwyer, C. A., Geisinger, K. R., Marx, R. W., Noell, G. H., Pianta, R. C., .. Worrell, F. C. (2016). Assessing the assessments of teacher preparation. Theory Into Practice, 55(2), 160 167. https://doi.org/10.1080/00405841.2015.1036667

Bridgeman, B., Pollack, J., \& Burton, N. (2008). Predicting grades in different types of college courses (College Board Research Report No. 2008-1, ETS RR-08-06). New York, NY: The College Board.

Cabrera, A., Nora, A., Terenzini, P., Pascarella, E., \& Hagedorn, L. (1999). Campus racial climate and the adjustment of students to college: A comparison between white students and AfricanAmerican students. The Journal of Higher Education, 70(2), 134-160. https://doi.org/10. $2307 / 2649125$

Camara, W. J., \& Echternacht, G. (2000). The SAT I and high school grades: Utility in predicting success in college. Research Notes RN-10, The College Board, Office of Research and Development.

Cole, D. A. (1987). Utility of confirmatory factor analysis in test validation research. Journal of Consulting and Clinical Psychology, 55, 584-594. https://doi.org/10.1037/0022-006X.55.4. 584

Coolahan, J. (2003). Attracting, developing and retaining effective teachers: Country background report for Ireland. Dublin, Ireland: Department of Education and Science.

Corcoran, R. P. (2017a). Preparing teachers' to raise students' mathematics learning. International Journal of Science and Mathematics Education, https://doi.org/10.1007/s10763-017-9819-1

Corcoran, R. P. (2017b). Preparing principals to improve student achievement. Child \& Youth Care Forum, https://doi.org/10.1007/s10566-017-9399-9

Corcoran, R. P., \& O'Flaherty, J. (2016a). Personality development during teacher preparation. Frontiers in Psychology, 7, 1677. https://doi.org/10.3389/fpsyg.2016.01677

Corcoran, R. P., \& O'Flaherty, J. (2016b). Moral reasoning development among college students: A growth curve analysis. Journal of Moral Education, 45(4), 433-448. https://doi.org/10.1080/ 03057240.2016 .1230051

Corcoran, R. P., \& O'Flaherty, J. (2017). Executive function during teacher preparation. Teaching and Teacher Education, 63, 168-175. https://doi.org/10.1016/j.tate.2016.12.023

Corcoran, R. P., \& Tormey, R. (2012). How emotionally intelligent are pre-service teachers? Teaching and Teacher Education, 28, 750-759. https://doi.org/10.1016/j.tate.2012.02.007

Corno, L., \& Mandinach, E. B. (2004). What we have learned about student engagement in the past twenty years. In D. M. McInerney \& S. Van Etten (Eds.), Big theories revisited (pp. 299-328). Greenwich, CT: Information Age.

Davis-Kean, P. E., \& Jager, J. (2014). Trajectories of achievement within race/ethnicity: "Catching up" in achievement across time. The Journal of Educational Research, 107, 197-208. https:// doi.org/10.1080/00220671.2013.807493

Diseth, A., \& Kobbeltvedt, T. (2010). A mediation analysis of achievement motives, goals, learning strategies, and academic achievement. British Journal of Educational Psychology, 80, 671687. https://doi.org/10.1348/000709910X492432 
Duckworth, A. L., Peterson, C., Matthews, M. D., \& Kelly, D. R. (2007). Grit: Perseverance and passion for long-term goals. Journal of Personality and Social Psychology, 92, 1087-1101. https://doi.org/10.1037/0022-3514.92.6.1087

Dweck, C. S. (1999). Self-theories: Their role in motivation, personality and development. Philadelphia, PA: The Psychology Press.

Dweck, C. S. (2015). Growth. BritishJournal of Educational Psychology, 85, 242-245. https://doi. org/10.1111/bjep.12072

Elliott, J. (1993). Reconstructing teacher education: Teacher development. London, UK: Falmer Press.

Ensminger, M. E., \& Slusarcick, A. L. (1992). Paths to high school graduation or dropout: A longitudinal study of a first-grade cohort. Sociology of Education, 65, 95-113. https://doi.org/ $10.2307 / 2112677$

Glazerman, S., Loeb, S., Goldhaber, D., Staiger, D., Raudenbusch, S., \& Whitehurst, G. (2010). Evaluating teachers: The important role of value added. Washington, DC: Brown Center on Education Policy at Brookings.

Gormley, I. C., \& Murphey, T. B. (2006). Analysis of Irish third-level college applications data. Journal of the Royal Statistical Society: Series A, Statistics in Society, 169, 361-379. https://doi. org/10.1111/j.1467-985X.2006.00412.x

Greene, J. J., \& Forster, G. (2003). Public high school graduation and college readiness rates in the United States. Education Working Paper \#3. Manhattan Institute.

Grimm, K. J. (2008). Longitudinal associations between reading and mathematics achievement. Developmental Neuropsychology, 33, 410-426. https://doi.org/10.1080/87565640801982486

Harris, D. N. (2012). How do value-added indicators compare to other measures of teacher effectiveness?. New York, NY: Carnegie Foundation.

Hattie, J. (2015). The applicability of visible learning to higher education. Scbolarship of Teaching and Learning in Psychology, 1, 79-91. https://doi.org/10.1037/st10000021

Hedeker, D., \& Gibbons, R. D. (2006). Longitudinal data analysis. Hoboken, NJ: Wiley.

Hill, H. C., Rowan, B., \& Loewenberg Ball, D. (2005). Effects of teachers' mathematical knowledge for teaching on student achievement. American Educational Research Journal, 42, 371-406. https://doi.org/10.3102/00028312042002371

Hirsh, J. B., Mar, R. A., \& Peterson, J. B. (2012). Psychological entropy: A framework for understanding uncertainty-related anxiety. Psychological Review, 119, 304-320. https://doi. org/10.1037/a0026767

Ishitani, T., \& Desjardins, S. (2002). A longitudinal investigation of dropout from college in the United States. Journal of College Student Retention: Research, Theory and Practice, 4(2), 173201. https://doi.org/10.2190/v4en-nw42-742q-2ntl

Johnson, V. E. (1997). An alternative to traditional GPA for evaluating student performance. Statistical Science, 12, 251-278.

Kim, E., \& Corcoran, R. P. (2017). How engaged are pre-service teachers in the United States? Teaching and Teacher Education, 66, 12-23. https://doi.org/10.1016/j.tate.2017.03.020

King, R. B., \& McInerney, D. M. (2014). Mapping changes in students' English and math selfconcepts: A latent growth model study. Educational Psychology, 34, 581-597. https://doi.org/ 10.1080/01443410.2014.909009

Kobrin, J. L., Patterson, B. F., Shaw, E. J., Mattern, K. D., \& Barbuti, S. M. (2008). The validity of the SATfor predicting first-year college grade point average (College Board Research Report 20082005). New York, NY: The College Board.

Leonard, D., \& Gleeson, J. (1999). Context and coherence in initial teacher education in Ireland: The place of reflective inquiry. Teacher Development, 3, 49-63. https://doi.org/10.1080/ 13664539900200070

Locke, E. A., \& Latham, G. P. (2002). Building a practically useful theory of goal setting and task motivation: A 35-year odyssey. American Psychologist, 57, 705-717. https://doi.org/10.1037/ $0003-066 \times 57.9 .705$

Lynch, K. (1989). The bidden curriculum. London, UK: The Falmer Press. 
Marsh, H. W., Balla, J. R., \& McDonald, R. P. (1988). Goodness-of-fit indexes in confirmatory factor analysis: The effect of sample size. Psychological Bulletin, 103, 391-410. https://doi.org/10. 1007/BF01102761

Martin, A. J. (2007). Examining a multidimensional model of student motivation and engagement using a construct validation approach. British Journal of Educational Psychology, 77, 413-440. https://doi.org/10.1348/000709906X118036

Martin, A. J. (2013). Goal orientation. In J. Hattie \& E. M. Anderman (Eds.), International guide to student achievement (pp. 353-355). New York, NY: Routledge.

Martin, A. J. (2015). Implicit theories about intelligence and growth (personal best) goals: Exploring reciprocal relationships. British Journal of Educational Psychology, 85, 207-223. https://doi. org/10.1111/bjep.12038

Martin, A. J., \& Liem, G. A. (2010). Academic personal bests (PBs), engagement, and achievement: A cross-lagged panel analysis. Learning and Individual Differences, 20, 265-270. https://doi.org/ 10.1016/j.lindif.2010.01.001

Mattern, K. D., \& Patterson, B. F. (2011a). The relationship between SAT scores and retention to the fourth year: 2006 validity sample (College Board Statistical Report 2011-2006). New York, NY: The College Board.

Mattern, K. D., \& Patterson, B. F. (2011b). The relationship between SAT scores and retention to the third year: 2006 validity sample (College Board Statistical Report 2011-2006). New York, NY: The College Board.

McCoach, D. B., Madura, J., Rambo-Hernandez, K. E., O'Connell, A. A., \& Welsh, M. (2013). Longitudinal data analysis. In T. Teo (Ed.), Handbook of quantitative methods for educational research (pp. 199-230). Rotterdam, The Netherlands: Sense.

McDonald, R. P., \& Marsh, H. W. (1990). Choosing a multivariate model: Noncentrality and goodness of fit. Psychological Bulletin, 107(2), 247-255. https://doi.org/10.1037/0033-2909.107.2.247

McManus, I. C., Woolf, K., Dacre, J., Paice, E., \& Dewberry, C. (2013). The academic backbone: Longitudinal continuities in educational achievement from secondary school and medical school to MRCP(UK) and the specialist register in UK medical students and Doctors. BMC Medicine, 11, 242-269. https://doi.org/10.1186/1741-7015-11-242

MET Project (2012). Asking students about teaching: Student perception surveys and their implementation. Seattle, WA: Bill and Melinda Gates Foundation.

Metallidou, P., \& Vlachou, A. (2010). Children's self-regulated learning profile in language and mathematics: The role of task value beliefs. Psychology in the Schools, 47, 776-788. https://doi. org/10.1002/pits.20503

Mok, M. M. C., McInerney, D. M., Zhu, J., \& Or, A. (2015). Growth trajectories of mathematics achievement: Longitudinal tracking of student academic progress. British Journal of Educational Psychology, 85, 154-171. https://doi.org/10.1111/bjep.12060

Morisano, D., Hirsh, J. B., Peterson, J. B., Pihl, R. O., \& Shore, B. M. (2010). Setting, elaborating, and reflecting on personal goals improves academic performance. Journal of Applied Psychology, 95, 255-264. https://doi.org/10.1037/a0018478

Musset, P. (2010). Initial teacher education and continuing training policies in a comparative perspective: Current practices in OECD countries and a literature review on potential effects. OECD Education Working Papers, No. 48, OECD. https://doi.org/10.1787/5kmbphh7s47h-en

Muthen, B. O., \& Khoo, S. T. (1998). Longitudinal studies of achievement growth using latent variable modeling. Learning and Individual Differences, 10, 73-101. https://doi.org/10.1016/ s1041-6080(99)80135-6

Muthen, B., \& Muthen, L. (2011). Mplus (Version 6.12) [Computer software]. Los Angeles, CA: Author.

Noble, J., \& Sawyer, R. (2002). Predicting different levels of academic success in college using high school GPA and ACT composite score, ACT Research Report Series 2002-4. Retrieved from http://files.eric.ed.gov/fulltext/ED469746.pdf 
O'Flaherty, J., \& Gleeson, J. (2017). Irish student teachers' levels of moral reasoning: Context, comparisons, and contributing influences. Teachers and Teaching: Theory and Practice, 23(1), $59-77$.

Organisation for Economic Co-operation and Development (OECD) (1991). Reviews of national policies for education: Ireland. Paris, France: Author.

Organisation for Economic Co-operation and Development (OECD) (2005). Teachers matter: Attracting, developing and retaining effective teachers. Paris, France: Author.

Pascarella, E. T., Pierson, C. T., Wolniak, G. C., \& Terenzini, P. T. (2004). First-generation college students: Additional evidence on college experiences and outcomes. Journal of Higher Education, 75, 249-284.

Pascarella, E., \& Terenzini, P. (2005). How college affects students, Volume 2: A third decade of research. San Francisco, CA: Jossey-Bass.

Perry, R. P., Hladkyj, S., Pekrun, R. H., Clifton, R. A., \& Chipperfield, J. G. (2005). Perceived academic control and failure in college students: A three-year study of scholastic attainment. Research in Higher Education, 46, 535-569. https://doi.org/10.1007/s11162-005-3364-4

Pinxten, M., Marsh, H. W., De Fraine, B., van den Noortgate, W., \& van Damme, J. (2014). Enjoying mathematics or feeling competent in mathematics? Reciprocal effects on mathematics achievement and perceived math effort expenditure. British Journal of Educational Psychology, 84, 152-174. https://doi.org/10.1111/bjep.12028

Raudenbush, S. W. (2001). Comparing personal trajectories and drawing causal inferences from longitudinal data. Annual Review of Psychology, 52, 501-525. https://doi.org/10.1146/annure v.psych.52.1.501

Ready, D. D. (2013). Associations between student achievement and student learning: Implications for value-added school accountability models. Educational Policy, 27, 92-120. https://doi.org/ $10.1177 / 0895904811429289$

Rescorla, L., \& Rosenthal, A. S. (2004). Growth in standardized ability and achievement test scores from 3rd to 10th grade. Journal of Educational Psychology, 96(1), 85-96. https://doi.org/10. 1037/0022-0663.96.1.85

Rumberger, R. W. (1995). Dropping out of middle school: A multilevel analysis of students and schools. American Educational Research Journal, 32, 583-625.

Schunk, D. H. (2008). Learning theories: An educational perspective. Upper Saddle River, NJ: Pearson Education.

Seijts, G. H., Latham, G. P., \& Woodwark, M. (2013). Learning goals: A qualitative and quantitative review. In E. A. Locke \& G. P. Latham (Eds.), New developments in goal setting and task performance (pp. 195-212). New York, NY: Routledge.

Shin, T. (2007). Comparison of three growth modeling techniques in the multilevel analysis of longitudinal academic achievement scores: Latent growth modeling, hierarchical linear modeling, and longitudinal profile analysis via multidimensional scaling. Asia Pacific Education Review, 8, 262-275. https://doi.org/10.1007/bf03029261

Shin, T., Davison, M. L., Long, J. D., Chen, C. K., \& Heistad, D. (2013). Exploring gains in reading and mathematics achievement among regular and exceptional students using growth curve modelling. Learning and Individual Differences, 23, 92-100. https://doi.org/10.1016/j.lindif. 2012.10.002

Strenta, A. C., \& Elliot, R. (1987). Differential grading revisited. Journal of Educational Measurement, 24, 281-291.

Strenta, A. G., Elliott, R., Adair, R., Matier, M., \& Scott, J. (1994). Choosing and leaving science in highly selective institutions. Research in Higher Education, 35, 513-547. https://doi.org/10. 1007/BF02497086

Stumpf, H., \& Stanley, J. C. (2002). Group data on high school grade point averages and scores on academic aptitude tests as predictors of institutional graduation rates. Educational and Psychological Measurement, 62, 1042-1052. https://doi.org/10.1177/0013164402238091

Teaching Council (2011). Initial teacher education: Criteria and guidelines for programme providers. Maynooth, Ireland: Author. Available at: http://www.teachingcouncil.ie/_fileupload/ 
Teacher\%20Education/Final\%20Criteria\%20and\%20Guidelines\%20for\%20Existing\%20Progs\% 20Aug2011.pdf

Teaching Council of Ireland (2013). Guidelines on school placement. Available at: http://www.teac hingcouncil.ie/_fileupload/Teacher\%20Education/School\%20Placement/School\%20Placement \%20Guidelines.pdf

Travers, C. J., Morisano, D., \& Locke, E. A. (2015). Self-reflection, growth goals, and academic outcomes: A qualitative study. British Journal of Educational Psychology, 85, 224-241. https://doi.org/10.1111/bjep.12059

Walvoord, B. E. (2010). Assessment clear and simple (2nd ed.). San Francisco, CA: Jossey-Bass.

Weisberg, D., Sexton, S., Mulhern, J., \& Keeling, D. (2009). The widget effect: Our national failure to acknowledge and act on differences in teacher effectiveness. Washington, DC: The New Teacher Project.

Westrick, P. A., Le, H., Robbins, S. B., Radunzel, J. M. R., \& Schmidt, F. L. (2015). College performance and retention: A meta-analysis of the predictive validities of $\mathrm{ACT}^{\circledR} \mathrm{scores,} \mathrm{high} \mathrm{school} \mathrm{grades,} \mathrm{and}$ SES. Educational Assessment, 20, 23-45. https://doi.org/10.1080/10627197.2015.997614

Worrell, F., Brabeck, M., Dwyer, C., Geisinger, K., Marx, R., Noell, G., \& Pianta, R. (2014). Assessing and evaluating teacher preparation programs. Washington, DC: American Psychological Association.

Yuan, K. H., \& Bentler, P. M. (2000). Three likelihood-based methods for mean and covariance structure analysis with nonnormal missing data. Sociological Methodology, 30(1), 165-200. https://doi.org/10.1111/0081-1750.00078

Zwick, R. (2006). Higher education admission testing. In R. Brennan (Ed.), Educational measurement (4th ed., pp. 647-679). Westport, CT: American Council on Education, Praeger.

Received 23 May 2016; revised version received 24 May 2017 